\title{
ANTI-GIARDIA ACTIVITY OF TANACETUM VULGARE FLOWERS EXTRACT ON INFECTED MICE
}

\author{
MARIA LUCIA MURESAN ${ }^{1}$, ANAMARIA COZMA-PETRUT ${ }^{2 *}$, DANIELA BENEDEC ${ }^{2 \#,}$ \\ CORNELIA REVNIC ${ }^{2}$, DANIELA HANGANU ${ }^{2}$, ELENA DINTE $^{2}$, ANAMARIA BALEA $^{3}$, \\ ILIOARA ONIGA ${ }^{2 \#}$
}

\author{
1 "Lucian Blaga" University, Faculty of Medicine, 2 A Lucian Blaga Street, 550169, Sibiu, Romania \\ 2 "Iuliu Haţieganu” University of Medicine and Pharmacy, Faculty of Pharmacy, 8 V. Babeș Street, 400010, Cluj-Napoca, \\ Romania \\ ${ }^{3}$ University of Agricultural Sciences and Veterinary Medicine, Faculty of Veterinary Medicine, 3-5 Calea Mănăștur Street, \\ 400372, Cluj-Napoca, Romania
}

*corresponding author: anamaria.cozma@umfcluj.ro

${ }^{\#}$ Authors with equal contribution.

Manuscript received: January 2021

\begin{abstract}
The Giardia duodenalis infection is considered one of the common pathologies caused by flagellated protozoa in humans, and medicinal plants are important sources of antiprotozoal agents with fewer side effects. The aim of this study was to evaluate the anti-Giardia activity of Tanacetum vulgare L. (Asteraceae), common tansy flowers hydroalcoholic extract. The experiment was conducted on mice infected with G. muris, using metronidazole and Giardiplant ${ }^{\circledR}$ (a commercial product) for comparison. After 5 days of treatment, the $G$. muris trophozoites count in the small intestine was significantly decreased $(p<0.01)$ in the group treated with $T$. vulgare tincture, compared to the group treated with metronidazole. The obtained results have shown that T. vulgare flowers extract has in vivo anti-Giardia effects and it can be considered a promising natural alternative for the treatment of giardiasis.
\end{abstract}

\section{Rezumat}

Infecția cu Giardia duodenalis este una din cele mai frecvente infecții cu protozoare flagelate la om, iar plantele medicinale reprezintă surse importante pentru obținerea de agenți antiprotozoare cu mai puține efecte secundare. Scopul acestui studiu a fost evaluarea activității anti-Giardia a extractului hidroalcoolic din flori de Tanacetum vulgare L. (Asteraceae), vetrice. Experimentul s-a realizat pe șoareci infectați cu G. muris, folosind metronidazol și Giardiplant ${ }^{\circledR}$ (un produs comercial) pentru comparație. După 5 zile de tratament, tinctura de T. vulgare a determinat scăderea semnificativă a numărului de trofozoiți de G. muris din intestinul subțire $(\mathrm{p}<0,01)$, efect comparabil cu al metronidazolului. Rezultatele obținute au arătat că extractul din flori de T. vulgare are acțiune anti-Giardia in vivo și poate fi considerat o alternativă naturală promițătoare pentru tratamentul giardiozei

Keywords: Tanacetum vulgare, tansy flowers, mice, anti-Giardia activity

\section{Introduction}

Giardia is a genus of flagellated protozoan parasites for which six species are currently recognised, including Giardia agilis in amphibians, Giardia ardeae and Giardia psittaci in birds, Giardia muris and Giardia microti in rodents and Giardia duodenalis in mammals [12]. Giardia duodenalis (syn. Giardia intestinalis, Giardia lamblia) is the only species found in humans, although it has also been reported in domestic, farmed and wild animals [21]. The current sub-classification of $G$. duodenalis indicates the heterogeneity of the organism that consists of eight (A-H) assemblages with human infections are caused by assemblages $\mathrm{A}$ and $\mathrm{B}$; these can also infect other mammalian hosts with demonstrated potential for zoonotic transmission $[12,14]$. As the recognised etiological agent of giardiasis in people, G. duodenalis is responsible for gastro- intestinal infections with severity ranging from asymptomatic to watery diarrhoea, associated with abdominal pain, malabsorption and body weight loss. Giardiasis is regarded as a parasitic disease of great epidemiological and clinical importance, due to its high prevalence and pathogenicity in animals as well as in humans. Although the incidence of giardiasis across the world has diminished in the last decade, a high number of cases are still reported, involving high risk of transmission and important costs. Among the drugs recommended for the treatment of giardiasis, metronidazole is the first choice, followed by others such as tinidazole, albendazole and furazolidone [1, 11]. These medications could be associated with drug resistance and potential risks of mutagenicity and carcinogenicity, as well as multiple undesirable side effects (e.g., metallic taste, headache, dry mouth, glossitis) 
$[1,11]$. Finding alternative solutions becomes imperative and in this regard, plants from several genres: Artemisia, Allium, Curcuma, Cinnamomum, Mentha, Origanum, Punica, Trigonella, Satureja, Tanacetum, Zingiber etc. have been studied and recommended as safe alternatives [2, 5-10, 17, 23, 24, 27-29]. Species of the genus Tanacetum have been used as medicinal plants for more than 2000 years [15]. Tanacetum vulgare L. (Asteraceae family), common tansy, is traditionally used to treat intestinal worms, rheumatism, digestive problems, in many countries, including Romania [18, 19, 26]. The flowers contain phenolic compounds (luteolin, apigenin, chlorogenic and caffeic acids), essential oil (with thujone, cineole), carotenoids, sesquiterpene lactones (eudesmanolides, parthenolide) [3, $15,16,20,30]$. Several studies have evaluated certain therapeutic properties, such as anti-inflammatory, antioxidant, antimicrobial, antiviral and antitumor activity $[3,4,15]$. To our knowledge, $T$. vulgare flowers extract has not been studied before for anti-Giardia activity, however it is empirical used as anthelmintic drug [5]. Therefore, the aim of the present study was to evaluate the in vivo anti-Giardia activity of tansy tincture. The study of the phytochemical composition and the analysis of the polyphenolic and volatile compounds from $T$. vulgare flowers were previously performed $[15,16]$.

\section{Materials and Methods}

Plant material, extraction procedure

The flowers of $T$. vulgare were collected during the blossom period (June, 2017) from the spontaneous flora of Transylvania, Cluj County, Romania. A specimen of these plants is deposited at the Department of Pharmacognosy, Faculty of Pharmacy Cluj-Napoca, Romania, (Voucher no. 26). The tincture (1:10) was prepared as follows: the plant material powder was extracted with $70 \%$ ethanol, using a simple maceration process, according to the method described in the Romanian Pharmacopoeia [31].

Experimental design and animals

The anti-Giardia activity was evaluated after the administration of three medicinal products: tincture of T. vulgare, Giardiplant ${ }^{\circledR}$ (Plafar SA, Romania) and metronidazole, respectively. Giardiplant ${ }^{\circledR}$ is a commercial phytotherapeutic product (containing Calendula officinalis hydro-alcoholic extract, T. vulgare hydro-alcoholic extract and Thymi aetheroleum), commonly used in giardiasis. In order to ensure the physical stability of the extractive products, $T$. vulgare tincture and the commercial product Giardiplant ${ }^{\circledR}$ were diluted with a micellar dispersion of $1 \%$ Tween 80 , corresponding to obtain suitable volumes for administration. Metronidazole (chosen as antiprotozoal drug control) was administered as a suspension in 1\% methylcellulose mucilage. The tested products were administrated by oral gavage in a single dose of $0.2 \mathrm{~mL} / \mathrm{mouse} /$ day, each administration containing the established dose of treatment: $0.08 \mathrm{~g} \mathrm{~T}$. vulgare tincture, $0.16 \mathrm{~g}$ Giardiplant ${ }^{\circledR}$ and $0.016 \mathrm{~g}$ metronidazole, respectively [22, 25, 27, 29]. Sixty male Swiss albino mice, free from any intestinal parasitic infection, aged 3 weeks and weighing $20 \pm$ $5 \mathrm{~g}$ each (at the beginning of the experiment) were used. The animals were housed in a temperature and light-controlled room $\left(21^{\circ} \mathrm{C}\right.$, a $12 \mathrm{~h}$ cycle starting at 08:00 h) and were fed and allowed to drink water $\mathrm{ad}$ libitum. The animals were divided into 6 groups, 10 mice in each group: Group 1 - positive control, infected; Group 2 - negative control, uninfected; Group 3 infected, received a saline solution $(0.9 \% \mathrm{NaCl})$, placebo; Group 4 - infected, received T. vulgare tincture $(0.08$ $\mathrm{g} /$ mouse/day); Group 5 - infected, received Giardiplant ${ }^{\circledR}$ (0.16 g/mouse/day); Group 6 - infected, received a suspension of metronidazole (0.016 g/mouse/day) [25]. Animals' infection, confirmation of the infection and treatment

The mice from groups 1, 3, 4, 5 and 6 were intragastrically infected with 1 x $10^{5}$ Giardia muris cysts/ $\mathrm{mL}$. The infectious material was obtained from 10 sacrificed mice, already infected with G. muris (from the Laboratory Animal Facility of UASVM ClujNapoca, Romania), which was mixed with $0.9 \% \mathrm{NaCl}$ solution. The infection of mice was confirmed by intestinal examination, using a direct microscopic method (200x magnification), to reveal Giardia trophozoites [25]. Subsequently, fresh faecal pellets were collected and examined every $24 \mathrm{~h}$ to prove the experimental infection, using the Blagg method with some modifications, to reveal Giardia cysts [25]. Throughout the experiment, the mice were kept under the same conditions, in terms of maintenance status (the bedding was replaced every 2 days) and nutrition, and their clinical status was also constantly monitored [2, 25, 29].

Prior to treatment, on the eighth day after infection and on the tenth day after infection, respectively, control sacrifices were performed from each group, with one mouse per group being sacrificed. The duodenal mucosa was scraped in $0.9 \% \mathrm{NaCl}$ solution, and the viability and number of parasites were monitored by direct microscopic examination method (200x magnification). The intensity of infection was evaluated by counting the identified parasites in microscopic fields. The count was done on 10 microscopic fields, and then the average/field was determined [25]. After 8 days, the groups 3, 4, 5 and 6 received the treatments presented above. Faecal samples were collected at the beginning of the experiment (day 1), at the beginning of treatment (day 8), after 3 days of treatment (day 10) and at the end of treatment (day 12), then analysed by the Blagg method with some modifications, to reveal Giardia cysts [25]. The treatment duration was 5 days. On the sixth day (day 13 of the experiment), all mice were sacrificed to evaluate the number of G. muris vegetative forms (trophozoites) in the small intestine. The efficacy of the 
therapy was assessed by direct microscopic examination (200x magnification) of duodenal scraping. Attachment of Giardia spp. trophozoites to enterocytes is essential for colonization of the small intestine and it is considered a prerequisite for parasite-induced enterocyte dysfunction and clinical disease. The duodenum of each mouse was removed and placed in a Petri dish containing 1 $\mathrm{mL} 0.9 \% \mathrm{NaCl}$ solution. This dish was vortexed to release the trophozoites from the intestinal wall. Trophozoites were counted using a haemocytometer, in ten fields, with 20x microscopic lens [13, 25].

\section{Ethical considerations}

The mice were treated in accordance with the guidelines of animal bioethics from the Act on Animal Experimentation and Animal Health and Welfare from Romania and all procedures were in compliance with Directive 2010/63/EU of the European Parliament and of the Council of 22 September 2010 on the protection of animals used for scientific purposes. According to the $43 / 2014$ national law for the protection of animals used for scientific purposes, the project was approved by the Commission for Bioethics and Research Ethics of UASVM and also, efforts were made to minimize animal suffering and to reduce the number of used animals.

Statistical analysis

T-test was used for comparison between control and treated groups. The p-value $<0.05$ was considered as significant difference between groups. Data were displayed as mean $\pm \mathrm{SD}$.

\section{Results and Discussion}

The results of investigating the in vivo effect of $T$. vulgare extract on mice experimentally infected with G. muris are shown in Table I and Figure 1. Metronidazole was used as antigiardial drug and Giardiplant ${ }^{\circledR}$, a commercial product, was chosen only for comparison, due to its content in $T$. vulgare extract.

Table I

Giardia muris trophozoites count for the studied groups

\begin{tabular}{|c|c|c|c|}
\hline \multirow[b]{2}{*}{ Groups } & \multicolumn{3}{|c|}{ Trophozoites count average/field } \\
\hline & $\begin{array}{c}\text { Day } 8 \\
\left(1^{\text {st }} \text { day of treatment }\right)\end{array}$ & $\begin{array}{c}\text { Day 10 } \\
\left(3^{\text {rd }} \text { day of treatment }\right)\end{array}$ & $\begin{array}{c}\text { Day 13 } \\
\text { (after 5 days of treatment) }\end{array}$ \\
\hline $\begin{array}{c}1 \text { - infected, } \\
\text { without treatment (positive control, Pc) }\end{array}$ & $54.9 \pm 2.10$ & $55.2 \pm 0.80$ & $55.22 \pm 0.87$ \\
\hline $\begin{array}{c}2 \text { - uninfected } \\
\text { (negative control, } \mathrm{Nc} \text { ) }\end{array}$ & 0 & 0 & 0 \\
\hline $\begin{array}{l}\text { 3 - infected, } \\
\text { saline treatment (placebo, } P \text { ) }\end{array}$ & $51.8 \pm 1.20$ & $50.8 \pm 0.20$ & $51.63 \pm 0.77$ \\
\hline $\begin{array}{c}4 \text { - infected, } \\
\text { Tanacetum vulgare extract treatment (TvE) }\end{array}$ & $51.6 \pm 1.40$ & $10.4 \pm 0.40$ & $2.11 \pm 0.38^{\mathrm{a}}$ \\
\hline $\begin{array}{c}5 \text { - infected, } \\
\text { Giardiplant }{ }^{\circledR} \text { treatment }(G)\end{array}$ & $39.8 \pm 2.20$ & $14.1 \pm 0.10$ & $6.08 \pm 0.15^{\mathrm{b}, \mathrm{e}}$ \\
\hline $\begin{array}{c}6 \text { - infected, } \\
\text { metronidazole treatment }(M)\end{array}$ & $28.6 \pm 1.20$ & $14.4 \pm 0.90$ & $2.45 \pm 0.68^{\mathrm{c}, \mathrm{d}}$ \\
\hline
\end{tabular}

The values represent the average of three determinations \pm SD. ${ }^{a} \mathrm{p}<0.01$ (group 1 versus group 4 ), ${ }^{b} \mathrm{p}<0.01$ (group 1 versus group 5), ${ }^{c} \mathrm{p}<0.01$ (group 1 versus group 6), ${ }^{\mathrm{d}} \mathrm{p}>0.05$ (group 4 versus group 6), ${ }^{\mathrm{e}} \mathrm{p}<0.01$ (group 4 versus group 5).

Thus, on the $3^{\text {rd }}$ day of treatment, the $T$. vulgare tincture showed significant activity against flagellates (p < 0.01), with the G. muris trophozoites number decreasing from $51.6 \pm 1.40$ to $10.4 \pm 0.40$ trophozoites/ field, while metronidazole and Giardiplant ${ }^{\circledR}$ produced a decrease of up to about 14 (Table I, Figure 1). After 5 days of treatment, $T$. vulgare tincture greatly reduced the count of trophozoites of G. muris in the duodenum (2.11 \pm 0.38 trophozoites/field), comparable with metronidazole $(2.45 \pm 0.68)$, and more effective than Giardiplant $^{\circledR}(6.08 \pm 0.15, \mathrm{p}<0.01)$. The T. vulgare tincture could affect the attachment of trophozoites, leading to their sliding and disintegration from the intestinal mucosa [13]. Our tincture exhibited a significant reduction in the number of trophozoites recovered from the intestine, compared to the positive control (group $1 ; \mathrm{p}<0.01$ ). However, there were no significant differences between $T$. vulgare extract treated group (group 4) and Metronidazole treated group (group 6) $(\mathrm{p}>0.05)$.

According to Table I, significant differences $(p<0.01)$ were observed between the positive group (group 1) and Giardiplant ${ }^{\circledR}$ group (group 5), and metronidazole group (group 6), respectively.

Previous studies have evaluated the anti-Giardia activity for hydro-alcoholic extracts of Rosmarinus officinalis [27], Mentha x piperita [28], Origanum vulgare [6], known for their rich polyphenolic content. High concentrations of some phenolic compounds, such as phenolic acids (gallic, ellagic, caffeic, p-coumaric, vanillic acid) or flavonoids (quercetin), were related with the giardicidal activity of pomegranate peel methanolic extract [29]. Another research showed that higher levels of phenolic compounds (chlorogenic acid, rosmarinic acid, flavonoids) from Origanum vulgare extract could be responsible for anti-Giardia activity, by interacting with cysts membrane [6]. 


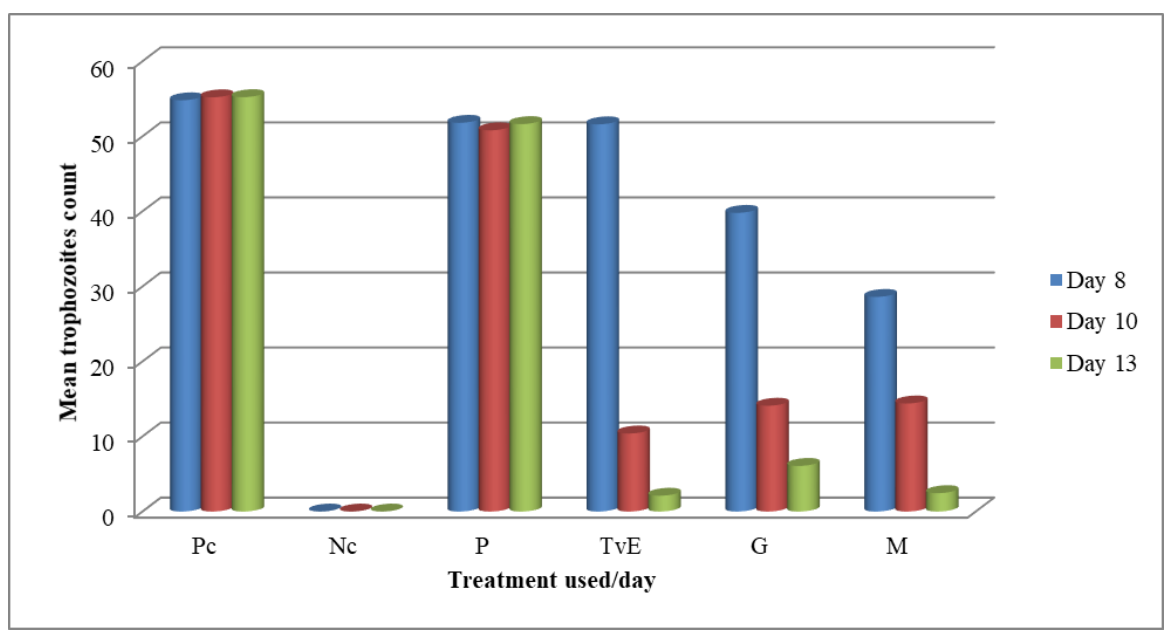

Figure 1.

Giardia muris trophozoites count for control, infected and treated groups in the $8^{\text {th }}, 10^{\text {th }}$ and $13^{\text {th }}$ days $\mathrm{Pc}=$ positive control, $\mathrm{Nc}=$ negative control, $\mathrm{P}=$ placebo, $\mathrm{TvE}=T$. vulgare extract treatment, $\mathrm{G}=$ Giardiplant ${ }^{\circledR}$ treatment, $\mathrm{M}=$ metronidazole treatment

The phenolic compounds identified in our previous research on T. vulgare flowers (phenolic acid derivatives: chlorogenic, p-coumaric, ferulic acids and flavonoids: quercitrin, hyperoside, rutin, isoquercitrin, quercetin, apigenin, luteolin) [15], as well as the terpenes, could be involved in the efficacy of treating the infection caused by Giardia spp. Through this first study in vivo that used the experimental infection with $G$. muris as a model, the potential therapeutic effect of T. vulgare tincture in giardiasis illness is sustained, as a promising alternative to the antiprotozoal drugs commonly administered.

\section{Conclusions}

To our knowledge, this is the first study to evaluate and demonstrate the anti-Giardia effect of the T. vulgare tincture in mice experimentally infected with G. muris. Our results provide relevant scientific proof of the in vivo efficacy of tansy flowers tincture in the treatment of infections caused by G. muris, comparable with Metronidazole, but without its adverse reactions. The $T$. vulgare extract can be considered a promising alternative to anti-Giardia drugs recommended for the treatment of giardiasis, and this study may direct further research concerning its efficacy against other flagellated parasites.

\section{Conflict of interest}

The authors declare no conflict of interest.

\section{References}

1. Adam RD, Biology of Giardia lamblia. Clin Microbiol Rev., 2001; 14(3): 447-475.

2. AL-Khfaji MSA, Antigiardial activity of garlic (Allium sativum) on white mice. Journal of Babylon University / Pure and Applied Sciences, 2017; 25(3): 1105-1110.
3. Alvarez AL, Habtemariam S, Juan-Badaturuge M, Jackson C, Parra F, In vitro anti HSV-1 and HSV-2 activity of Tanacetum vulgare extracts and isolated compounds: an approach to their mechanisms of action. Phytother Res., 2011; 25(2): 296-301.

4. Coté H, Boucher MA, Pichette A, Legault J, Antiinflammatory, antioxidant, antibiotic, and cytotoxic activities of Tanacetum vulgare $\mathrm{L}$. essential oil and its constituents. Medicines, 2017; 4(2): 1-9.

5. Davoodi J, Abbasi-Maleki S, Comparison anti-giardia activity of Satureja hortensis alcoholic extract and metronidazole in vitro. Adv Herb Med., 2016; 2(2): 15-21.

6. Davoodi J, Abbasi-Maleki S, Effect of Origanum vulgare hydroalcoholic extract on Giardia lamblia cysts compared with metronidazole in vitro. Iran J Parasitol., 2018; 13(3): 486-492.

7. Dyab AK, Yones DA, Ibraheim ZZ, Hassan TM, Anti-giardial therapeutic potential of dichloromethane extracts of Zingiber officinale and Curcuma longa in vitro and in vivo. Parasitol Res., 2016; 115(7): 26372645.

8. Elmi T, Gholami Sh, Azadbakht M, Ziaie H, Effect of chloroformic extract of Tanacetum parthenium in the treatment of Giardia lamblia infection in balb/c mice. J Mazand Univ Med Sci., 2014; 24: 157-165.

9. Gholami S, Azadbakht M, Hezarjaribi HZ, RahimiEsboei B, Anti-giardial activity of chloroformic extract of Tanacetum parthenium and Artemisia annua in vitro. Res Mol Med., 2014; 2(1): 45-50.

10. Hezarjaribi HZ, Elmi T, Dayer MS, Gholami, S Fakhar M, Akbariqomi M, A systematic review of the effects of Iranian pharmaceutical plant extracts on Giardia lamblia. Asian Pac J Trop Dis., 2015; 5(12): 925-929.

11. Hooshyar H, Rostamkhani P, Arbabi M, Delavari M, Giardia lamblia infection: review of current diagnostic strategies. Gastroenterol Hepatol Bed Bench., 2019; 12(1): 3-12.

12. Li J, Wang H, Wang R, Zhang L, Giardia duodenalis infections in humans and other animals in China. Front Microbiol., 2017; 8: 2004. 
13. Mahmoud A, Attia R, Said S, Ibraheim Z, Ginger and cinnamon: can this household remedy treat giardiasis? Parasitological and histopathological studies. Iran J Parasitol., 2014; 9(4): 530-534.

14. Mircean V, Györke A, Cozma V, Prevalence and risk factors of Giardia duodenalis in dogs from Romania. Vet Parasitol., 2012; 184(2-4): 325-329.

15. Mureșan ML, Benedec D, Vlase L, Oprean R, Toiu A, Oniga I, Screening of polyphenolic compounds, antioxidant and antimicrobial properties of Tanacetum vulgare from Transylvania. Studia UBB Chemia, 2015; 60(1): 127-138.

16. Mureșan ML, Oniga I, Georgescu C, Păltinean R, Gligor F, Crăciunaș MT, Oprean R, Botanical and phytochemical studies on Tanacetum vulgare $\mathrm{L}$. from Transylvania. Acta Medica Transilvanica, 2014; 2(4): 300-302.

17. Najumudin K, Ayubu J, Elnazeer A, Antigiardial activity of some plant extracts used in traditional medicine in Sudan in comparison with metronidazole. Microbiol Curr Res., 2018; 2(4): 75-79.

18. Piras A, Falconieri D, Bagdonaite E, Maxia A, Gonçalves MJ, Cavaleiro C, Salgueiro L, Porcedda $\mathrm{S}$, Chemical composition and antifungal activity of supercritical extract and essential oil of Tanacetum vulgare growing wild in Lithuania. Nat Prod Res., 2014; 28(21): 1906-1909.

19. Polosky Z, $21^{\text {st }}$ Century homesteads: biological pest control. ${ }^{\text {st }}$ Edition. Morrisville, United States, 2015; 144-146.

20. Rosselli S, Bruno M, Raimondo FM, Spadaro V, Varol M, Koparal AT, Maggio A, Cytotoxic effect of eudesmanolides isolated from flowers of Tanacetum vulgare ssp. siculum. Molecules, 2012; 17: 8186-8195.

21. Ryan U, Cacciò SM, Zoonotic potential of Giardia. Int J Parasitol., 2013; 43(12-13): 943-956.

22. Sizemore CF, Quispe JD, Amsler KM, Modzelewski TC, Merrill JJ, Stevenson DA, Foster LA, Slee AM, Effects of metronidazole, tetracycline, and bismuthmetronidazole-tetracycline triple therapy in the Helicobacter pylori SS1 mouse model after 1 day of dosing: development of an $H$. pylori lead selection model. Antimicrob Agents Chemother., 2002; 46(5): 1435-1440.

23. Scheau C, Mihai LG, Bădărău IA, Căruntu C, Emerging applications of some important natural compounds in the field of oncology. Farmacia, 2020; 68(6): 984-991.

24. Stan RL, Sevastre B, Ionescu C, Olah NK, Vicaș LG, Páll E, Moisa C, Hanganu D, Sevastre-Berghian AC, Andrei S, Pripon-Furtuna FR, Marcus I, Hangan AC, Artemisia annua L. extract: a new phytoproduct with sod-like and antitumour activity. Farmacia, 2020; 68(5): 812-821.

25. Şuteu E, Cozma V, Morar R, Ognean L, Goga L, Cercetări privind eficacitatea Eridiaromului în infestaţia experimentală cu flagelați: Giardia, Trichomonas şi Hexamitis la şoareci de laborator. Sem Inst Agro: Cluj, 1989; 16: 285-291, (available in Romanian).

26. Tămaș M, Pharmaceutical botany. Vol. III. Medicală Universitară "Iuliu Hațieganu” Cluj-Napoca Publishing House, 1999; 232-233 (available in Romania).

27. Vazini H, Rahimi Esboie B, Abedian R, Ghorbani A, Fathi H, Comparing the effect of hydroalcoholic extract of rosemary and metronidazole in treating infection caused by Giardia lamblia in mice under in vivo conditions. J Babol Univ Med Sci., 2017; 19(6): 50-56.

28. Vidal F, Vidal JC, Gadelha AP, Lopes CS, Coelho MG, Monteiro-Leal LH, Giardia lamblia: The effects of extracts and fractions from Mentha x piperita Lin. (Lamiaceae) on trophozoites. Exp Parasitol., 2007; 115: 25-31.

29. Wafa AM, In vivo study of pomegranate (Punica granatum) peel extract efficacy against Giardia lamblia in infected experimental mice. Asian Pac J Trop Biomed., 2017; 7: 59-63.

30. Zolotaikina MY, Hontova TM, Kotov AH, Ilyina TV, Kryvoruchko OV, Study of dry extract of tansy (Tanacetum vulgare) using the method of HighPerformance Liquid Chromatography. Pharma Chem., 2017; 9(11): 1-4.

31. xxx - Romanian Pharmacopoeia, ed. a X-a. Medicală Publishing House, Bucureşti, 1993, (available in Romanian). 